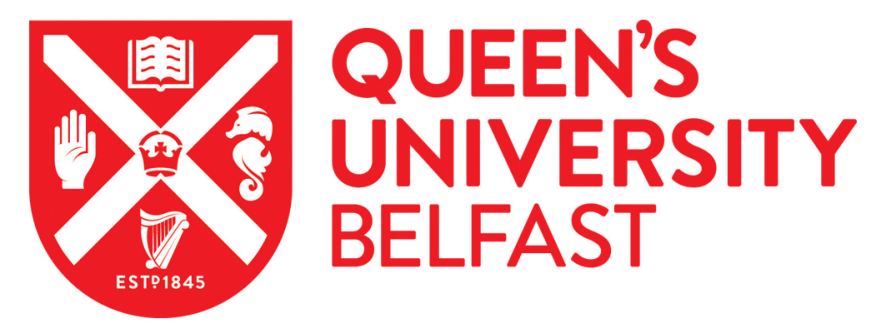

\title{
HLA haplotypes and TNF polymorphism do not associate with longevity in the Irish
}

Ross, O. A., Curran, M. D., Rea, M., Hyland, P., Duggan, O., Barnett, C. R., Annett, K., Patterson, C., Barnett, Y. A., \& Middleton, D. (2003). HLA haplotypes and TNF polymorphism do not associate with longevity in the Irish. Mechanisms of Ageing and Development, 124(4), 563-567. https://doi.org/10.1016/S0047(03)00037-x

\section{Published in:}

Mechanisms of Ageing and Development

Queen's University Belfast - Research Portal:

Link to publication record in Queen's University Belfast Research Portal

\section{General rights}

Copyright for the publications made accessible via the Queen's University Belfast Research Portal is retained by the author(s) and / or other copyright owners and it is a condition of accessing these publications that users recognise and abide by the legal requirements associated with these rights.

Take down policy

The Research Portal is Queen's institutional repository that provides access to Queen's research output. Every effort has been made to ensure that content in the Research Portal does not infringe any person's rights, or applicable UK laws. If you discover content in the Research Portal that you believe breaches copyright or violates any law, please contact openaccess@qub.ac.uk. 


\title{
HLA haplotypes and TNF polymorphism do not associate with longevity in the Irish
}

\author{
Owen A. Ross ${ }^{\mathrm{a}, \mathrm{b}, *}$, Martin D. Curran ${ }^{\mathrm{a}, \mathrm{c}}$, I. Maeve Rea ${ }^{\mathrm{d}}$, Paul Hyland ${ }^{\mathrm{b}}$, Orla Duggan ${ }^{\mathrm{b}}$, \\ Christopher R. Barnett ${ }^{\mathrm{b}}$, Kathryn Annett ${ }^{\mathrm{b}}$, Chris Patterson ${ }^{\mathrm{e}}$, Yvonne A. Barnett ${ }^{\mathrm{b}}$, \\ Derek Middleton $^{\mathrm{a}, \mathrm{b}, \mathrm{c}}$ \\ ${ }^{a}$ Northern Ireland Regional Histocompatibility and Immunogenetics Laboratory, Blood Transfusion Building, City Hospital, Belfast BT9 7 TS, Northern \\ Ireland, $U K$ \\ ${ }^{\mathrm{b}}$ School of Biomedical Sciences, University of Ulster, Coleraine, Northern Ireland, UK \\ ${ }^{\mathrm{c}}$ School of Biology and Biochemistry, Queens University of Belfast, Belfast, Northern Ireland, UK \\ ${ }^{\mathrm{d}}$ Department of Geriatric Medicine, Queens University of Belfast, Belfast, Northern Ireland, UK \\ ${ }^{\mathrm{e}}$ Department of Epidemiology and Public Health, Queens University of Belfast, Belfast, Northern Ireland, UK
}

Received 26 June 2002; received in revised form 10 July 2002; accepted 20 December 2002

\begin{abstract}
Polymorphism of the human leukocyte antigen has been implicated in a number of autoimmune disorders including ageing. In the course of the present study, no association of the human leukocyte antigen (HLA)-A1, B8, DR3 haplotype with a male Irish aged population, as previously reported, was observed. Two polymorphic nucleotides in the TNF cluster $(\mathrm{G}-308 \mathrm{~A}$ TNF- $\alpha$ and $\mathrm{G}+252 \mathrm{~A}$ TNF- $\beta$ ), associated with increased TNF- $\alpha$ production, were shown to be in tight linkage disequilibrium with the class I and II HLA loci, generating HLA haplotypes with extended linkage disequilibrium. However, no age-related allele or genotype frequencies were observed for either polymorphic nucleotide.
\end{abstract}

(C) 2003 Elsevier Science Ireland Ltd. All rights reserved.

Keywords: HLA; TNF; Polymorphism; Immunosenescence

\section{Introduction}

Human longevity would appear to be inextricably linked with optimal functioning of the immune system, suggesting that specific genetic determinants may reside in polymorphic loci that regulate the immune response. Dysregulation of immune function accompanying ageing (immunosenescence) is postulated to contribute to morbidity and mortality in the aged via an increased risk of disease, infection, tumours, and autoimmune disorders (Franceschi et al., 1995; Pawelec and Solana, 1997; Franceschi et al., 1998; Makinodan, 1998; Solana and

\footnotetext{
* Corresponding author. Tel.: +44-28-90263883; fax: +44-2890263880 .

E-mail address: owenaross@hotmail.com (O.A. Ross).
}

Pawelec, 1998; Pawelec, 1999; Franceschi et al., 2000; Malaguarnera et al., 2001). The highly polymorphic human leukocyte antigen (HLA) complex is located on chromosome $6 \mathrm{p} 21$ and is divided into three regions containing class I, class III and class II genes, respectively. In spite of the pivotal role that the polymorphic HLA antigens play in immunosurveillance and the immune response, and the multitude of studies performed, conclusive evidence of association with successful longevity has remained elusive (Reviewed in Caruso et al., 2000, 2001).

The majority of studies so far have focused on the action of class I and II HLA loci, but there are many class III genes with the potential to modulate immune function, such as the TNF genes. The TNF locus is located within the central HLA class III region, and the multiple pro- and anti-inflammatory activities of TNF 
and related cytokines in the TNF cluster, make them attractive targets along with other HLA genes for unravelling the molecular mechanisms underlying the development of many diseases and ageing. TNF genes display strong linkage disequilibrium with HLA class I and II genes and defects in TNF production may contribute to HLA-associated disorders. Polymorphism at two nucleotides $(\mathrm{G}-308 \mathrm{~A}$ TNF- $\alpha$ and $\mathrm{G}+252 \mathrm{~A}$ TNF- $\beta$ ) is associated with increased TNF- $\alpha$ production (Makhatadze, 1998; Hajeer and Hutchinson, 2001; Lio et al., 2001).

An increase in the frequency of the HLA haplotype A1B8Cw7DR3 was previously reported by Rea and Middleton (1994) in elderly males in the northern Irish population and this haplotype has also been associated with an enhanced TNF- $\alpha$ production (Lio et al., 1997, 2001). The aim of the present study was to establish the presence of this longevity marker in males from the north of Ireland and to evaluate the contribution polymorphism within the TNF cluster has on longevity.

\section{Materials and methods}

\subsection{Subjects}

One hundred control samples ( $59 \%$ female, $41 \%$ male with an age-range of 19-45 years old) were chosen at random from the archival DNA bank of normal healthy Caucasian individuals from the Northern Ireland population stored at the Northern Ireland Histocompatibility and Immunogenetics Laboratory of Belfast City Hospital. Ninety-three aged samples ( $70 \%$ female, $30 \%$ male with an age-range of 80-97 years old) from the Belfast Elderly Longitudinal Free-living Ageing Study were also included in the study (Rea et al., 2000). All DNA samples were from healthy aged Caucasian individuals from the Northern Ireland population displaying no signs of age-related disorders, still living independently and approximating SENIEUR status (Ligthart et al., 1984, 1990). There was no duplication with respect to the samples used for the previous study (Rea and Middleton, 1994).

\subsection{HLA-A, $-B$ and $-D R$ typing}

The aged and control subjects were HLA-A, -B and DR typed by sequence specific oligonucleotide probes (SSOP) as previously reported (Middleton et al., 2000).

\subsection{PCR amplification of the TNF regions}

The oligonucleotide primers employed for the amplification of the $107 \mathrm{bp}$ region of the TNF- $\alpha$ and the 772 $b p$ region of the TNF- $\beta$ genes were as reported (adapted from Barber et al., 1999):
TNF- $\alpha \mathrm{F}: 5^{\prime}$-AGGCAATAGGTTTTGAGGGCCAT-3'

TNF- $\alpha$ R: $5^{\prime}$-TCCTCCCTGCTCCGATTCCG-3'

TNF- $\beta$ F: 5'-CCGTGCTTCGTGCTTTGGACTA-3'

TNF- $\beta$ R: 5'-AGAGGGGTGGATGCTTGGGTTC-3'

PCR amplification was performed in $50 \mu \mathrm{l}$ reaction volumes containing $67 \mathrm{mM}$ Tris $-\mathrm{HCl} \mathrm{pH} 8.8 ; 16 \mathrm{mM}$ $\left(\mathrm{NH}_{4}\right)_{2} \mathrm{SO}_{4} ; 1.5 \mathrm{mM} \mathrm{MgCl} 2 ; 0.01 \%$ (w/v) Tween; 100 $\mu \mathrm{M}$ of each dNTP; $0.1 \mu \mathrm{M}$ of each primer; 1 unit Taq polymerase (Bioline UK Ltd, London, UK); 0.1-0.5 $\mu \mathrm{g}$ DNA. The following cycling conditions were employed; samples were held at $96{ }^{\circ} \mathrm{C}$ for $5 \mathrm{~min}$, followed by 35 cycles of $96^{\circ} \mathrm{C}$ for $1 \mathrm{~min}, 60^{\circ} \mathrm{C}$ for $1 \mathrm{~min}, 72^{\circ} \mathrm{C}$ for 1 min. After the final cycle, the samples were held at $72{ }^{\circ} \mathrm{C}$ for $5 \mathrm{~min}$, and then at $15{ }^{\circ} \mathrm{C}$ until removed from the PCR machine (Perkin-Elmer 9600 Thermal Cycler). Successful amplification was confirmed using gel electrophoresis on a $1 \%$ agarose gel stained with ethidium bromide $(0.5 \mu \mathrm{g} / \mathrm{ml})$.

\subsection{TNF polymorphism genotyping by SSOP}

Amplified DNA $(2 \mu \mathrm{l})$ was applied to a charged nylon membrane as reported (Middleton et al., 1995). Hybridisations, stringent washes and chemiluminescence detection of the hybridised digoxigenin-labelled probes were carried out as recently reported (Williams et al., 1999). The DNA sequence of the probes with the polymorphic nucleotide underlined were:

$\begin{array}{lll}\text { TNF- } & \text { GCCATG A GGAC- } & 54{ }^{\circ} \mathrm{C} / 20 \text { pico- } \\ \alpha A & \text { GGGGT } & \text { moles } \\ \text { TNF- } & \text { GCCATG G GGACGG- } & 58{ }^{\circ} \mathrm{C} / 20 \text { pico- } \\ \alpha G & \text { GGT } & \text { moles } \\ \text { TNF- } & \text { CTGCCATG A TTCCT- } & 52^{\circ} \mathrm{C} / 20 \text { pico- } \\ \beta A & \text { CTC } & \text { moles } \\ \text { TNF- } & \text { CTGCCATG G TTCCT- } & 56{ }^{\circ} \mathrm{C} / 20 \text { pico- } \\ \beta G & \text { CTC } & \text { moles }\end{array}$

Stringent wash temperatures and concentrations for each of the probes were empirically determined and are given above.

\subsection{DNA sequence analysis}

Purified PCR products (Qiagen QIAquick PCR purification kit, Qiagen Ltd, Sussex, UK) of a number of samples displaying homozygote profiles for each of the TNF polymorphisms analysed were sequenced on a 373A automated DNA sequencer (Curran et al., 1996), using the amplification primers at a concentration of 3.2 picomoles, to confirm the specificity of the amplification, and the exact location and sequence of the polymorphic nucleotide encountered. 


\subsection{Haplotype analysis}

Using the acquired allele data, HLA-A, -B, -DR, TNF- $\alpha$ and TNF- $\beta$, five loci haplotypes were estimated by the expectation-maximisation algorithm using the ARLEQUIN software package (Schneider et al., 2000). To test for departures from Hardy-Weinberg a Markovchain random walk algorithm was used (Guo and Thompson, 1992) also implemented in ARLEQUIN.

\subsection{Statistical analysis}

Fisher's exact probability tests were performed to assess whether the frequency differences observed between the aged and control groups for haplotypes and the TNF polymorphisms were statistically significant using the computer package 'MICROSTAT'. The males as a group and females as a group within each experimental age category were also assessed for statistically significant frequency differences using the same approach. Multiple comparisons were taken into account by employing Bonferroni's correction, $\alpha=1-0.95^{1 / n}$ (where $n$ is equal to the number of comparisons), and the level of statistical significance adjusted accordingly.

\section{Results and discussion}

The dysregulation of the immune function that accompanies ageing may be directed by polymorphism in the genes of the immune system. The highly polymorphic HLA is of crucial importance for immunosurveillance within the body and is associated with a number of autoimmune disorders and ageing.

The individual HLA-A, -B, -DR antigens and two single nucleotide polymorphisms of the TNF cluster were determined and the frequency of extended HLA haplotypes, incorporating the TNF polymorphisms, were analysed using the ARLEQUIN software package (Schneider et al., 2000). There was no evidence of significant departure from Hardy-Weinberg equilibrium for the samples when a Markov-chain random walk algorithm was used (Guo and Thompson, 1992). As expected, a high degree of polymorphism was observed between the individuals of this study, with the most common haplotypes presented in Table 1.

In recent times, a plethora of studies have been performed in an attempt to fully resolve the role polymorphism of the HLA has in longevity. However, to date, a large body of conflicting data has been amassed (Caruso et al., 2000, 2001). The present study set out to specifically confirm the previously reported increase in the frequency of the HLA-A1, -B8, -DR3 haplotype (22.9 vs $8.7 \%)$ in aged males of the northern Irish population (Rea and Middleton, 1994).
The results of this study did not reveal any statistically significant haplotype frequency differences between the aged cohort of individuals in comparison to the younger controls, or when analysed with respect to gender. When the haplotype analysis was performed the two polymorphic markers in the TNF genes were observed to be in tight linkage disequilibrium with the HLA haplotypes. The extended HLA-A1, -B8, -DR3, TNF- $\alpha$ A, TNF- $\beta$ G haplotype was not observed to increase within the aged group as a whole $(11.3 \%)$ in comparison to the controls $(12.8 \%)$. When the data was analysed with respect to gender, a slight increase was observed in the aged males $(7.1 \%)$ compared to the younger control male $(6.1 \%)$. In contrast, a decrease was observed when the aged females $(13.1 \%)$ were compared to the control females $(17.8 \%)$. It should be noted that the numbers recruited into this study are not sufficiently large enough to provide the statistical power needed to exclude a more subtle effect on ageing.

One of the most characteristic features of the HLA$\mathrm{A} 1,-\mathrm{B} 8,-\mathrm{DR} 3$ haplotype is the increased spontaneous release of TNF- $\alpha$, and this haplotype is also associated with a high in vivo and in vitro production of TNF- $\alpha$ (Lio et al., 1997, 2001). On this basis it was decided to include two polymorphic nucleotide markers in the TNF cluster, also associated with increased TNF- $\alpha$ production, in the haplotype analysis (Hajeer and Hutchinson, 2001). The individual frequencies of the two genetic variants were also assessed for association with the Irish aged population in this study (Table 2). However, no significant frequency differences in the genotype or allele frequencies were observed for either the $\mathrm{G}-308 \mathrm{~A}$ TNF$\alpha$ or $\mathrm{G}+252 \mathrm{~A}$ TNF- $\beta$ polymorphic markers for either the two age groups as a whole or when the data was analysed with respect to gender.

The frequency of HLA antigens is largely dependent upon the geographic location of the study population (Caruso et al., 2000, 2001). In this study, the homogeneous nature of the population from the north of Ireland, coupled with low levels of immigration due to the regions troubled past, has helped to alleviate some of the potential bias. The extremely polymorphic nature of the HLA complex creates a diverse range of haplotypes, thus lowering the power of the subsequent statistical analysis. Major limitations in the studies reported to date are the number of aged individuals available, and complete background histories of health or ethnicity for study participants. It is proposed that HLA haplotype frequencies are often affected by environmental determinants such as a famine or an epidemic (Izaks et al., 2000). The evidence accumulated to date would suggest that there are a number of gender-specific HLA haplotypes associated with successful ageing in different geographic regions. To fully elucidate the role of the HLA in longevity broad studies need to be performed integrating the many HLA typing laboratories through- 
Table 1

The observed frequencies of the most common HLA and TNF polymorphic haplotypes in the healthy aged individuals and the young controls

\begin{tabular}{|c|c|c|c|c|c|c|c|}
\hline Total & HLA-A & HLA-B & HLA-DRB1 & TNF- $\alpha$ & TNF- $\beta$ & Controls $n=100(\%)$ & Aged $n=93(\%)$ \\
\hline & 1 & 8 & 3 & A & $\mathrm{G}$ & 12.8 & 11.3 \\
\hline & 3 & 7 & 15 & G & A & 7.3 & 5.4 \\
\hline & 2 & 44 & 4 & G & A & 6 & zero \\
\hline \multirow[t]{5}{*}{ Males } & HLA-A & HLA-B & HLA-DRB1 & TNF- $\alpha$ & TNF- $\beta$ & Controls $n=41(\%)$ & Aged $n=28(\%)$ \\
\hline & 3 & 7 & 15 & G & A & 8.5 & 8.9 \\
\hline & 1 & 8 & 3 & A & G & 6.1 & 7.1 \\
\hline & 2 & 44 & 4 & $\mathrm{G}$ & A & 3.7 & 1.8 \\
\hline & 2 & 44 & 7 & G & G & 4.9 & \\
\hline \multirow[t]{5}{*}{ Females } & HLA-A & HLA-B & HLA-DRB1 & $\mathrm{TNF}-\alpha$ & TNF- $\beta$ & Controls $n=59(\%)$ & Aged $n=65(\%)$ \\
\hline & 1 & 8 & 3 & A & G & 17.8 & 13.1 \\
\hline & 3 & 7 & 15 & G & A & 6.8 & 3.9 \\
\hline & 2 & 44 & 4 & G & A & 5.8 & zero \\
\hline & 29 & 44 & 7 & G & A & 5.1 & - \\
\hline
\end{tabular}

Table 2

The observed allele and genotype frequencies for the two polymorphic markers of the TNF genes

\begin{tabular}{|c|c|c|c|c|c|c|}
\hline & \multicolumn{3}{|l|}{ Controls $n=100$} & \multicolumn{3}{|l|}{ Aged $n=93$} \\
\hline & Male $n=41(\%)$ & Female $n=59(\%)$ & Total $(\%)$ & Male $n=28(\%)$ & Female $n=65(\%)$ & Total $(\%)$ \\
\hline \multicolumn{7}{|c|}{ TNF- $\alpha$} \\
\hline $\mathrm{AA}$ & $2(5)$ & $5(8)$ & $7(7)$ & $1(4)$ & $7(11)$ & $8(9)$ \\
\hline $\mathrm{AG}$ & $11(27)$ & $21(36)$ & $32(32)$ & $9(32)$ & $22(34)$ & $31(33)$ \\
\hline GG & $28(68)$ & $33(56)$ & $61(61)$ & $18(64)$ & $36(55)$ & $54(58)$ \\
\hline A & $15(18)$ & $31(26)$ & $46(23)$ & $11(20)$ & $36(28)$ & $47(25)$ \\
\hline G & $67(82)$ & 87 (74) & $154(77)$ & $45(80)$ & $94(72)$ & $139(75)$ \\
\hline \multicolumn{7}{|c|}{ TNF- $\beta$} \\
\hline AA & $18(44)$ & $18(31)$ & $11(36)$ & $11(39)$ & $25(38)$ & $36(39)$ \\
\hline $\mathrm{AG}$ & $18(44)$ & $33(56)$ & $51(51)$ & $12(43)$ & $28(43)$ & $40(43)$ \\
\hline GG & $5(12)$ & $8(14)$ & $13(13)$ & $5(18)$ & $12(18)$ & $17(18)$ \\
\hline A & $54(66)$ & $69(58)$ & $123(61)$ & $34(61)$ & $78(60)$ & $112(60)$ \\
\hline $\mathrm{G}$ & $28(34)$ & $49(42)$ & 77 (39) & $22(39)$ & $52(40)$ & $74(40)$ \\
\hline
\end{tabular}

out Europe to increase the number of aged samples and provide a strong foundation for meta-analysis.

The high degree of polymorphism within the HLA region creates an opportunity where a unique immunological profile can be generated for individuals. This study attempted to widen the scope of HLA association studies by including polymorphism located in the class III region. Many class III genes have the potential to modulate immune function such as, complement proteins and the heat shock proteins and it is important to consider the effects that polymorphism of these genes may have during immunosenescence. The formation of immunogenetic profiles for successfully aged individuals incorporating such parameters as HLA haplotypes and cytokine gene polymorphism profiles will contribute to a resolution of the underlying molecular mechanisms occurring during immunosenescence.

\section{Acknowledgements}

The authors wish to acknowledge The European Union for support under the aegis of European Union Concerted Action on the Molecular Biology of Immunosenescence (EUCAMBIS; Biomed 1 contract CT941209); and Immunology and Ageing in Europe (IMAGINE; QLK6-CT-1999-O2031). OA Ross was a recipient of a CAST Award jointly funded by the Department of Education and Learning (Northern Ireland) and the Histocompatibility and Immunogenetics Charitable Trust Fund.

\section{References}

Barber, M.D., Powell, J.J., Lynch, S.F., Gough, N.J., Fearon, K.C., Ross, J.A., 1999. Two polymorphisms of the tumour necrosis 
factor gene do not influence survival in pancreatic cancer. Clin. Exp. Immunol. 117, 425-429.

Caruso, C., Candore, G., Colonna Romano, G., Lio, D., Bonafe, M., Valensin, S., Franceschi, C., 2000. HLA, aging, and longevity: a critical reappraisal. Hum. Immunol. 61, 942-949.

Caruso, C., Candore, G., Colonna Romano, G., Lio, D., Bonafe, M., Valensin, S., Franceschi, C., 2001. Immunogenetics of longevity. Is major histocompatibility complex polymorphism relevant to the control of human longevity? A review of literature data. Mech. Age Dev. 122, 445-462.

Curran, M.D., Williams, F., Earle, J.A.P., Rima, B.K., van Dam, M.G., Bunce, M., Middleton, D., 1996. Long-range PCR amplification as an alternative strategy for characterizing novel HLA-B alleles. Eur. J. Immunogenet. 23, 297-309.

Hajeer, A.H., Hutchinson, I.V., 2001. Influence of TNF- $\alpha$ gene polymorphisms on TNF- $\alpha$ production and disease. Hum. Immunol. 62, 1191-1199.

Franceschi, C., Monti, D., Barbieri, D., Grassilli, E., Troiano, L., Salvioli, S., Negro, P., Capri, M., Guido, M., Azzi, R., Sansoni, P., Paganelli, R., Fagiolo, U., Baggio, G., Donazzan, S., Mariotti, S., D'Addato, S., Gaddi, A., Ortolani, C., Cossarizza, A., 1995. Immunosenescence in humans: deterioration or remodelling? Int. Rev. Immunol. 12, 57-74.

Franceschi, C., Passeri, M., De Benedictis, G., Motta, L., 1998. Immunosenescence. Aging Clin. Exp. Res. 10 (2), 153-154.

Franceschi, C., Bonafe, M., Valensin, S., 2000. Human immunosenescence: the prevailing of innate immunity, the failing of clonotypic immunity, and the filling of immunological space. Vaccine 18, $1717-1720$

Guo, S., Thompson, E., 1992. Performing the exact test of HardyWeinberg proportion for multiple alleles. Biometrics 48, 361-372.

Izaks, G.J., Remarque, E.J., Schreuder, G.M., Westendorp, R.G., Ligthart, G.J., 2000. The effect of geographic origin on the frequency of HLA antigens and their association with ageing. Eur. J. Immunogenet. 27, 87-92.

Ligthart, G.J., Corberand, J.X., Fournier, C., Galanaud, P., Hijmans, W., Kennes, B., Muller-Hermelink, H.K., Steinmann, G.G., 1984. Admission criteria for immunogerontological studies in man: the SENIEUR protocol. Mech. Age Dev. 28, 47-55.

Ligthart, G.J., Corberand, J.X., Goertzen, H.G.M., Minders, A.E., Knook, D.L., Hijmans, W., 1990. Necessity of the assessment of health status in human immunogerontological studies: evaluation of the SENIEUR protocol. Mech. Age Dev. 55, 89-98.

Lio, D., Candore, G., Colonna Romano, G., D'Anna, C., Gervasi, F., Di Lorenzo, G., Modica, M.A., Potestio, M., Caruso, C., 1997.
Modification of cytokine patterns in subjects bearing the HLAB8,DR3 phenotype: implications for autoimmunity. Cytokines Cell Mol. Ther. 3, 217-224.

Lio, D., Candore, G., Colombo, A., Colonna Romano, G., Gervasi, F., Marino, V., Scola, L., Caruso, C., 2001. A genetically determined high setting of TNF- $\alpha$ influences immunologic parameters of HLA-B8,DR3 positive subjects: implications for autoimmunity. Hum. Immunol. 62, 705-713.

Makhatadze, N.J., 1998. Tumor necrosis factor locus: genetic organisation and biological implications. Hum. Immunol. 59, 571-579.

Makinodan, T., 1998. Studies on the influence of age on immune response to understand the biology of immunosenescence. Exp. Gerontol. 33 (1/2), 27-38.

Malaguarnera, L., Ferlito, L., Imbesi, R.M., Gulizia, G.S., Di Mauro, S., Maugeri, D., Malaguarnera, M., Messina, A., 2001. Immunosenescence: a review. Arch. Gerontol. Geriatr. 32, 1-14.

Middleton, D., Williams, F., Cullen, C., Mallon, E., 1995. Modification of an HLA-B PCR-SSOP typing system leading to improved allele determination. Tissue Antigens 45, 232-236.

Middleton, D., Curran, M.D., Williams, F., 2000. Immunogenetics and lifespan, HLA. In: Barnett, Y.A., Barnett, C.R. (Eds.), Methods in Molecular Medicine, Aging Methods and Protocols, vol. 38. Humana Press Inc, Totowa, NJ, USA.

Pawelec, G., Solana, R., 1997. Immunosenescence. Immunol. Today 18 (11), 514-516.

Pawelec, G., 1999. Immunosenescence: impact in the young as well as the old? Mech. Age Dev. 108, 1-7.

Rea, I.M., Middleton, D., 1994. Is the phenotypic combination A1B8Cw7DR3 a marker for male longevity? JAGS 42, 978-983.

Rea, I.M., McMaster, D., Woodside, J.V., Young, I.S., Archbold, G.P., Linton, T., Lennox, S., McNulty, H., Harmon, D.L., Whitehead, A.S., 2000. Community-living nonagenarians in Northern Ireland have lower plasma homocysteine but similar methylenetetrahydrofolate reductase thermolabile genotype prevalence compared to $70-89$-year-old subjects. Atherosclerosis 149, 207214.

Schneider, S., Roessli, D., Excofier, L. 2000. ARLEQUIN: a software for population genetics data analysis. Version 2.000 Genetics and Biometry Laboratory, Department of Anthropology, University of Geneva.

Solana, R., Pawelec, G., 1998. Molecular and cellular basis of immunosenescence. Mech. Age Dev. 102, 115-129.

Williams, F., Meenagh, A., Maxwell, A.P., Middleton, D., 1999. Allele resolution of HLA-A using oligonucleotide probes in a two stage typing strategy. Tissue Antigens 54, 59-68. 